\title{
Ability of mouse embryos to degranulate mast cells in vitro
}

\author{
A. Choroszewska and E. Mańkowska \\ Laboratory of Experimental Embryology, Department of Histology and Embryology, Medical School, \\ Chatubinskiego 5, 02-004 Warsaw, Poland
}

\begin{abstract}
Summary. Mouse embryos flushed from the reproductive tract on Day 4 or 5 post coitum degranulated peritoneal mast cells in vitro. The degranulating activity of embryos developed with age of embryos: it was absent with Day-3 embryos, present with Day-4 embryos and was increased with Day-5 embryos. Day-4 embryos cultured for $24 \mathrm{~h}$ also exhibited degranulating activity. Such activity was even greater for embryos cultured for $48 \mathrm{~h}$. As the degranulating activity of the incubated embryos increased, it was accompanied by an increase in the degranulating activity of the culture medium.
\end{abstract}

\section{Introduction}

Prostaglandins (Lau, Saksena \& Chang, 1973; Kennedy, 1977; Kennedy \& Lukash, 1982) and histamine (Shelesnyak, 1957; Johnson \& Dey, 1980) have been considered to be involved in the process of implantation and decidualization. These substances are stored and/or produced amongst others in mast cells (Uvnas, 1974; Lewis et al., 1982). The number of uterine mast cells decreases during oestrus (Harvey, 1964; Le Vier \& Spaziani, 1966; Maraspin \& Bo, 1971; Brandon \& Evans, 1983) and around the time of implantation (Shelesnyak, 1960; Brandon \& Bibby, 1979). The decrease of the numbers of uterine mast cells during oestrus and around the time of implantation is believed to be the result of degranulation of the mast cells caused by oestrogens (review: Spaziani, 1975). Although the number of uterine mast cells decreases during implantation, little is known of the effect of peri-implantation embryos on degranulation of mast cells.

In this study the degranulating activity of mouse embryos at different stages of development and the medium in which embryos were cultured was assessed by their action on the peritoneal mast cells of rats.

\section{Materials and Methods}

Mouse embryos recovered from the reproductive tract, mouse embryos cultured in vitro and the culture medium were used in the present study.

\section{Embryos and culture conditions}

The embryos were obtained after hormonally induced ovulation in mice of an outbred Swiss albino strain. The mice received 7.5 i.u. PMSG (Gestyl: Organon, Oss, The Netherlands) and 7.5 i.u. hCG (Pregnyl: Organon) $48 \mathrm{~h}$ apart. Nulliparous females were caged with outbred Swiss albino males of proven fertility and inspected for copulation plugs the next morning. The day on which the copulation plug was found was considered as Day 1 of pregnancy.

Early morulae were flushed with PBS from the oviduct on Day 3, later morulae and early blastocysts were flushed from the uterus on Day 4 and mature, zona-free blastocysts, probably 
from attachment sites (Finn \& McLaren, 1967; Theiler, 1972) were flushed from the uterus on Day 5 of pregnancy.

To test the degranulating activity of embryos which developed in vitro, Day-4 embryos were cultured for 24 or $48 \mathrm{~h}$ in a siliconized Petri dish, under paraffin oil gassed with a $5 \%$ mixture of $\mathrm{CO}_{2}$ with air at $37^{\circ} \mathrm{C}$. The medium for the $24 \mathrm{~h}$ culture was that described by Whitten (1971). After $24 \mathrm{~h}$ the embryos had developed to the blastocyst stage and had a rounded shape within the zonae pellucidae. The 48-h culture comprised two periods: the first $24 \mathrm{~h}$ was in Whitten's medium, and the second $24 \mathrm{~h}$ was in Eagle's medium supplemented with $1 \mathrm{mM}$-L-glutamine, $1 \mathrm{mM}$-sodium pyruvate (Sigma, St Louis, MO, U.S.A.), and 10\% fetal calf serum (Gibco, Grand Island, New York, U.S.A.). The change of culture medium for the second 24-h period is essential for obtaining the further development of blastocysts (Hsu, 1978). By the end of culture the zonae were shed and blastocysts showed a significant increase in size due to elongation and spreading.

To test whether embryos release the degranulating factor into the environment, the medium in which embryos were cultured was investigated. In each $0.05 \mathrm{ml}$ medium, 40 Day-4 embryos were placed under paraffin oil. They were cultured in Whitten's medium for $24 \mathrm{~h}$ (embryo culture medium I), and in the supplemented Eagle's medium for the next $24 \mathrm{~h}$ (embryo culture medium II). For the control experiments $0.05 \mathrm{ml}$ Whitten's or Eagle's medium was placed under paraffin oil in similar conditions but no embryos were used (control medium).

\section{Materials and incubation procedure}

The embryos were washed in cooled PBS and twice-distilled water, placed on a watchglass in $0.05 \mathrm{ml}$ twice-distilled water and freeze-dried. Under these conditions the zonae pellucidae and cells were disrupted. The dried material was covered with $0.05 \mathrm{ml}$ Whitten's medium and thoroughly mixed to provide an homogenate of embryo cells. The homogenates were prepared from 30 embryos in separate experiments. For early morulae (Day 3 of gestation) 5 additional experiments were conducted, in each of which 150 embryos were used for each homogenate. For the control experiments $0.05 \mathrm{ml}$ of twice-distilled water was placed in the watchglass and then freeze-dried. The dried material was covered with $0.05 \mathrm{ml}$ Whitten's medium and thoroughly mixed (control medium).

Degranulating activity was studied on mixed rat peritoneal cells, of which mast cells constitute about $40 \%$. Mast cells were obtained by washing the peritoneal cavity of female rats with $5 \mathrm{ml}$ PBS

Table 1. Mast cells degranulated by homogenates of mouse embryos developed in vivo

\begin{tabular}{lcccc}
\hline & & & \multicolumn{2}{c}{$\begin{array}{c}\text { Mean } \pm \text { s.e.m. no. of mast cells } \\
\text { degranulated by: }\end{array}$} \\
\cline { 4 - 5 } & $\begin{array}{c}\text { No. of } \\
\text { exps }\end{array}$ & $\begin{array}{c}\text { No. of } \\
\text { embryos }\end{array}$ & Embryos & Control medium \\
\hline $\begin{array}{l}\text { Day-3 embryos } \\
\text { (morulae) }\end{array}$ & 10 & 300 & $14 \cdot 5 \pm 1 \cdot 6^{*}$ & $12 \cdot 6 \pm 1 \cdot 2$ \\
$\begin{array}{l}\text { Day-4 embryos } \\
\text { (morulae and early } \\
\text { blastocysts) }\end{array}$ & 9 & 270 & $40 \cdot 0 \pm 2 \cdot 5^{*} \dagger$ & $8 \cdot 5 \pm 1 \cdot 1$ \\
$\begin{array}{l}\text { Day-5 embryos } \\
\text { (blastocysts from } \\
\text { attachment areas) }\end{array}$ & 8 & 240 & $60 \cdot 3 \pm 3 \cdot 1 \dagger$ & $8 \cdot 4 \pm 0 \cdot 8$ \\
\hline \begin{tabular}{l}
$*$ \\
\hline
\end{tabular} & & & & \\
$\dagger P<0 \cdot 001$. & & & & \\
\hline$P<001$.
\end{tabular}


supplemented with $1 \mathrm{mg}$ streptomycin, $1 \mathrm{mg}$ penicillin (Polfa, Warsaw, Poland) and $0 \cdot 1 \mathrm{mg}$ nystatin (E. R. Squibb \& Sons, London, U.K.). The liquid collected from one donor was centrifuged for 2 min at $18 \mathrm{~g}$. The supernatant was decanted and the residue was diluted with PBS so as to obtain 700-900 mast cells sedimented on a coverslip. Then, on the two opposite edges of a silicone-coated coverslip, $0.1 \mathrm{ml}$ PBS was placed to form two high drops. On the surface of each drop $0.05 \mathrm{ml}$ peritoneal fluid suspension was layered with a micropipette. A sediment formed within 90 sec and then the drops were poured off or delicately blotted with filter paper. Mast cells and a few other cells from the peritoneal fluid remained on the slides. They were covered with $0.05 \mathrm{ml}$ embryo homogenate (or embryo culture medium) on one edge, and with $0.05 \mathrm{ml}$ control medium on the other. The whole was then incubated in closed vessel, saturated with water vapour and a mixture of $5 \% \mathrm{CO}_{2}$ with air at $37^{\circ} \mathrm{C}$. The reaction was stopped by adding $0.05 \mathrm{ml} 20 \%$ formalin in PBS. After $20 \mathrm{~min}$ the supernatant was poured off and the mast cells remaining on the slides were stained with $0.02 \%$ acidified ( $\mathrm{pH} \mathrm{5)}$ toluidine blue solution in PBS for $3 \mathrm{~min}$.

By this method the mast cells were placed on a coverslip by sedimentation, thus avoiding the need of manipulation with a brush, and they remained there throughout the experiment. In this way any accidental influences of physical factors were eliminated. The sensitivity and repeatability of the method were checked by the incubation of mast cells with protamine sulphate (Biomed, Warsaw, Poland) (Choroszewska \& Mańkowska, 1983). The degranulated mast cells were counted under a light microscope. A mast cell was considered to be degranulated if there were at least 15 liberated granules nearby. The values were expressed as the mean \pm s.e.m. number of mast cells $/ 0.05 \mathrm{ml}$ peritoneal fluid suspension and were compared by Student's $t$ test.

\section{Results}

There were no significant differences between the mean number of mast cells degranulated by homogenates prepared from 30 Day-3 embryos and by control medium (Table 1). A similar result (not shown) was also obtained when the homogenates were prepared from 150 Day-3 embryos ( $18.2 \pm 1 \cdot 1$ and $12.6 \pm 1.2$ degranulated mast cells $/ 0.05 \mathrm{ml}$ peritoneal fluid).

The degranulating activity was detectable in Day-4 and Day-5 embryos and was greater for Day-5 than for Day-4 embryos (Table 1).

Table 2. Mast cells degranulated by homogenates of cultured mouse embryos and by the culture medium

\begin{tabular}{|c|c|c|c|c|}
\hline \multirow[b]{2}{*}{ Material } & \multirow[b]{2}{*}{$\begin{array}{l}\text { No. of } \\
\text { exps }\end{array}$} & \multirow[b]{2}{*}{$\begin{array}{l}\text { No. of } \\
\text { embryos }\end{array}$} & \multicolumn{2}{|c|}{$\begin{array}{l}\text { Mean } \pm \text { s.e.m. no. of } \\
\text { mast cells degranulated by: }\end{array}$} \\
\hline & & & $\begin{array}{l}\text { Embryos or } \\
\text { culture medium }\end{array}$ & Control medium \\
\hline Day-4 embryos & 9 & 270 & $40 \cdot 0 \pm 2 \cdot 5$ & $8 \cdot 5 \pm 1 \cdot 1$ \\
\hline $\begin{array}{l}\text { Day-4 embryos } \\
\text { cultured for } 24 \mathrm{~h}\end{array}$ & 8 & 240 & $53 \cdot 7 \pm 2 \cdot 8^{*}$ & $10 \cdot 1 \pm 0 \cdot 7$ \\
\hline $\begin{array}{l}\text { Day-4 embryos } \\
\text { cultured for } 48 \mathrm{~h}\end{array}$ & 8 & 240 & $70 \cdot 5 \pm 3 \cdot 3^{*}$ & $9 \cdot 0 \pm 0.4$ \\
\hline Culture medium I $\dagger$ & 8 & & $49 \cdot 1 \pm 2 \cdot 4$ & $9 \cdot 1 \pm 0.8$ \\
\hline Culture medium II & 8 & & $64 \cdot 5 \pm 1 \cdot 0^{*}$ & $8.7 \pm 0.6$ \\
\hline
\end{tabular}

†Whitten's medium in which Day-4 embryos were cultured for the first $24 \mathrm{~h}$. ¥Enriched Eagle's medium in which embryos were cultured for the second $24 \mathrm{~h}$.

${ }^{*} P<0.01$ compared to the value above. 
The degranulating activity was also detectable for embryos developed in vitro and in the culture medium (Table 2). In all experiments the mean number of mast cells degranulated by embryo homogenates or culture medium was significantly greater than that by control medium. The degranulating activity of embryos increased with the duration of embryo culture and it was accompanied by an increase in the degranulating activity of the culture medium.

\section{Discussion}

The present study revealed that homogenates of Day-4 and Day-5 mouse embryos degranulate mast cells in vitro. This seems to indicate that embryos in the peri-implantation period contain a factor(s) which reacts with mast cells and causes extrusion of cytoplasmic granules. The degranulating activity of embryos correlates with their age, but the increase in the degranulating activity is not connected with the increase in the number of blastomeres because the degranulating activity was not found in homogenates from 30 or from 150 Day-3 embryos. The activity is also not dependent on the protein content because in morulae and late blastocysts the total protein stays constant in spite of their increased volume (Brinster, 1967). The degranulating factor is not accumulated from the intraluminal environment because it occurs in embryos developing in the uterus and in vitro.

The degranulating activity of cultured embryos correlates with their stage of development; it is lower in rounded blastocysts still encased in the zona (cultured for $24 \mathrm{~h}$ ) and greater in elongated blastocysts that have spread and lost the zona (cultured for $48 \mathrm{~h}$ ). Degenerate embryos are inactive (Choroszewska \& Mańkowska, 1983). The interpretation of the above findings is that the degranulating activity may be the result of the biochemical differentiation of embryos and of the formation of new, biologically active compounds.

Peri-implantation mouse embryos also contain proteolytic enzymes (Andary, Dabich \& Van Winkle, 1972; Sherman, 1976) and enzyme systems which could synthesize oestrogens (Dickmann, Dey \& Sen Gupta, 1976; Sen Gupta, Roy \& Manchanda, 1982). Other studies indicate that trypsin degranulates mast cells (Archer, 1959), and local application of oestrone in the skin induces mast cell degranulation (Winer, Bierman \& Sternberg, 1963).

We conclude that (1) peri-implantation embryos are able to degranulate peritoneal mast cells in vitro, and (2) when embryos are cultured degranulating factor(s) is released into the medium. It therefore seems possible that a degranulating factor may be released from embryos in vivo into the uterus.

We thank Professor W. Sawicki for advice and guidance in the course of the present work. This research was supported by the Academy of Agriculture (grant MR II 10) and Small Supplies Programme of the WHO.

\section{References}

Andary, T.J., Dabich, D. \& Van Winkle, L.J. (1972) Changes in proteinase activity in early vs. late mouse blastocysts. J. Cell Biol. 55, 3a, Abstr.

Archer, G.T. (1959) The release of histamine from mast cells of the rat. Aust. J. exp. Biol. Med. Sci. 37, 383-389.

Brandon, J.M. \& Bibby, M.C. (1979) A study of changes in uterine mast cells during early pregnancy in the rat. Biol. Reprod. 20, 977-980.

Brandon, J.M. \& Evans, J.E. (1983) Changes in uterine mast cells during the estrous cycle in the Syrian hamster. Am. J. Anat. 167, 241-247.

Brinster, R.L. (1967) Protein content of the mouse embryo during the first five days of development. $J$. Reprod. Fert. 13, 413-420.
Choroszewska, A. \& Mańkowska, E. (1983) New method for determination of mast cells degranulation in vitro. Archvm Immun. Ther. exp. 31, 625-630.

Dickmann, Z., Dey, S.K. \& Sen Gupta, J.S. (1976) A new concept: control of early pregnancy by steroid hormones originating in the preimplantation embryo. Vitams Horm. 34, 215-242.

Finn, C.A. \& McLaren, A. (1967) A study of the early stages of implantation in mice. J. Reprod. Fert. 13, 259-267.

Harvey, E.B. (1964) Mast cells distribution in the uterus of cycling and pregnant hamster. Anat. Rec. 148, $507-515$.

Hsu, Y.C. (1978) In vitro development of whole mouse embryos beyond the implantation stage. In Methods 
in Mammalian Reproduction, pp. 229-245. Ed. J. C. Daniel Jr. Academic Press, New York.

Johnson, D.C. \& Dey, S.K. (1980) Role of histamine in implantation: dexamethasone inhibits estradiol induced implantation in the rat. Biol. Reprod. 22, 1136-1141.

Kennedy, T.G. (1977) Evidence for a role for prostaglandins in the initiation of blastocyst implantation in the rat. Biol. Reprod. 16, 286-29I.

Kennedy, T.G. \& Lukash, L.A. (1982) Induction of decidualization in rats by the intrauterine infusion of prostaglandins. Biol. Reprod. 27, 253-260.

Lau, J.F., Saksena, S.K. \& Chang, M.C. (1973) Pregnancy blockade by indomethacin, an inhibitor of prostaglandin synthesis: its reversal by prostaglandins and progesterone in mice. Prostaglandins 4, 795-803.

Le Vier, R.R. \& Spaziani, E. (1966) The effects of estradiol on the occurrence of mast cells in the rat uterus. Expl Cell Res. 41, 244-252.

Lewis, R.A., Soter, N.A., Diamond, P.T., Austen, K.F., Oates, J.A., Roberts, L.J., II (1982) Prostaglandin $\mathrm{D}_{2}$ generation after activation of rat and human mast cells with anti-IgE. J. Immunol. 129, 1627-1631.

Maraspin, L.E. \& Bo, W.K. (197I) Effects of hormones, pregnancy and pseudopregnancy on the mast cell count in the rat uterus. Life Sciences 10, 111-120.

Sen Gupta, J., Roy, S.K. \& Manchanda, S.K. (1982) Effect of an oestrogen synthesis inhibitor, 1,4,6-androstatriene-3,17-dione, on mouse embryo development in vitro. J. Reprod. Fert. 66, 63-66.
Shelesnyak, M.C. (1957) Some experimental studies on the mechanism of ova-implantation in the rat. Recent Progr. Horm. Res. 8, 269-322.

Shelesnyak, M.C. (1960) Nidation of the fertilized ovum. Endeavour 19, 81-86.

Sherman, M.I. (1976) Plasminogen activator in early embryogenesis: enzyme production by trophoblast and parietal endoderm. Cell 9, 231-240.

Spaziani, E. (1975) Accessory reproductive organs in mammals: control of cell and tissue transport by sex hormones. Pharmacol. Rev. 27, 207-286.

Theiler, K. (1972) Development and normal stage from fertilization to 4 weeks of age. In The House Mouse, Springer-Verlag, Berlin.

Uvnas, B. (1974) Histamine storage and release. Fedn Proc. Fedn Am. Socs exp. Biol. 33, 2172-2186.

Whitten, W.K. (1971) Nutrient requirements for the culture of preimplantation embryos in vitro. $A d v$. Biosci. 6, 129-141.

Winer, L.H., Bierman, S.M. \& Sternberg, T.H. (1963) Observations of acid mucopolysaccharide and mast cells in the skin of hairless mice following the tropical application of estrone and pregnenolone. J. invest. Derm. 41, 141-146. 